\title{
THE COMPLEXITIES OF LAW INTERPRETATION WITH REGARD TO THE INTERNATIONAL CRIMINAL COURT
}

\begin{abstract}
This article addresses one of the challenges faced by judges of the International Criminal Court, namely the interpretation of applicable legal provisions. The incompleteness of the Rome Statute, uncertainty as to the binding nature of relevant regulations, numerous general clauses - these are just some of the difficulties observed in the interpretation process. The aim of this short publication is to show the directives and types of interpretation used by the International Criminal Court, with particular reference to factors determining the process of interpretation. This article includes, inter alia, the analysis of relevant regulations, especially the Rome Statute and the Vienna Convention on the Law of Treaties, as well as the case law of the International Criminal Court. Considerations presented in this work are aimed at showing the specific character of interpretation conducted by the International Criminal Court.
\end{abstract}

\section{Keywords}

law interpretation - Rome Statute - International Criminal Court

\section{INTRODUCTION}

The International Criminal Court in the Hague (ICC) is the world's first supranational Court, established to exercise regular jurisdiction over

* PhD student, currently preparing doctoral thesis at the Faculty of Law and Administration, Jagiellonian University in Cracow. 
criminal matters ${ }^{1}$. The Rome Statute ${ }^{2}$ adopted in 1998 is the result of longlasting consultations, numerous compromises, and moreover, the result of a confrontation between two different legal traditions - common law and civil law. The willingness to combine these two legal systems, together with the multiplicity of views in preparatory commissions before the Rome conference in 1998, led to a situation where the Rome Statute does not fully cover all the legal problems which may appear before the Court. The Statute itself regulates, in general, only the most significant matters, providing the basic framework of legal structures and institutions. Many legal issues remain unclear, owing to imprecise legal concepts or general clauses used in certain provisions of the Statute. This applies in particular to the catalogue of sources of law which must be taken into account by the ICC judges while investigating the case and rendering the judgment.

The abovementioned factors have a considerable impact on the process of interpretation of international criminal law and the complexity of this interpretation. This short paper addresses the methodological problems relating to the process of law application by the ICC judges. It aims to show specific difficulties encountered during the interpretation of the law and to describe rules and forms of interpretation used by the ICC. The aim of this article is to present the specific character and role of interpretation in the ICC's work.

\section{DifFICULTIES IN THE PROCESS OF INTERPRETATION}

To begin with, it is essential to consider the terminology with regards to the interpretation of law. There are two views on the concept of interpretation in Polish legal theory, i.e. clarification theory (teoria klaryfikacyjna) and derivative theory (teoria derywacyjna) of interpretation. In this article, the term interpretation will be understood according to the clarification

${ }^{1}$ P. A. Kupis, Jurisdiction of the International Criminal Court, Poznań: Instytut Naukowo-Wydawniczy MAIUSCULA, 2014, p. 7.

2 Rome Statute of the International Criminal Court, signed at Rome on 17 July 1998, in force on 1 July 2002, United Nations, Treaty Series, vol. 2187, No. 38544, Depositary: Secretary-General of the United Nations, hereinafter referred to as "the Statute". 
theory, as a process which purpose is to define the meaning of a particular provision or its part ${ }^{3}$. It should be mentioned only, that the second, derivative concept assumes that the interpretation is the reconstruction of an unequivocal norm in the light of certain legal provisions. This concept however is not dominant in legal practice ${ }^{4}$.

The analysis of problems encountered by the ICC judges in the process of law interpretation should begin with the considerations on the sources of law that are being interpreted. It should be noted, that interpretational difficulties start at the stage of determining what is the relevant source of law and what can become the basis of the Court's judgment. In addition, as will be pointed out in further deliberations, the catalogue of sources of law and the way in which it is regulated, determines the character and role of interpretation.

The sources of law are enumerated in article 21 of the Statute, according to which the Court should apply the Statute, Elements of Crimes (EC), and Rules of Procedure and Evidence (RPE). Secondly, when it is appropriate, the Court will apply relevant treaties, principles, and rules of international law. Regarding this, the Statute places emphasis on the principles of the international law of armed conflict. Lastly, in the case of a lack of the aforementioned sources, the Court will apply general principles of law derived from the national laws of the world's legal systems, including the system of the State that would normally have jurisdiction over the crime. The condition under which such law may be applied is that it will not be inconsistent with the Statute, international law, and internationally recognized norms and standards. The analysis of this provision leads to the conclusion, that article 21 paragraph 1 of the Statute does not introduce the equivalency of legal sources - on the contrary, it establishes the hierarchy of these sources.

The Court has already commented on the premises in which judges can apply legal sources enumerated in paragraph $1 \mathrm{~b}$ and $1 \mathrm{c}$ of the article commented on, noting that these sources can be applied only under the condition that there is a lacuna in the written law (i.e. the Statute, Rules of Procedure, and Evidence or Elements of Crimes) that cannot be eliminated

${ }^{3}$ L. Morawski, Wykładnia w orzecznictwie sądów. Komentarz [Interpretation in courts' jurisprudence. Commentary], Torun: Dom Organizatora, 2002, p. 15.

${ }^{4}$ Ibid. 
by the criteria listed in the Vienna Convention on the law of treaties ${ }^{5}$. Naturally, the Rome Statute, as an international agreement, is subject to the rigours of interpretation specified in articles 31 and 32 of the Vienna Convention, but unfortunately, when it comes to the Convention, some difficulties may also arise. Article 31 of the Vienna Convention introduces the general rule of interpretation. In paragraph 1 the article commented on makes it obligatory to interpret treaties in "good faith", in accordance with the "ordinary meaning" of their content. Neither term has any legal definition and how they are understood may differ, depending on the circumstances and the interpreter. Finding the ordinary meaning of terms and phrases in many cases requires significant examination by the judge. However, when the problem of interpretation occurs, the Court refers to the abovementioned directives ${ }^{6}$. In this case, the ICC judges should at first solve interpretational problems from the written law perspective. Furthermore article 31 paragraph 1 of the Vienna Convention places emphasis, not only on the ordinary meaning of the terms of the treaty, but also requires treaties to be interpreted "in their context" and "in the light of their object and purpose". Although in article 31 paragraph 2 and 3, the Convention gives guidance on how to understand the term "context", the scope and the meaning of the " object and purpose" of the treaty is not so clear, since this term does not have such legal definition. Naturally, the general objects and purposes of particular treaties are often explicitly provided in their preambles. However, it still requires some additional activity on the part of the interpreter to specify them and in this way, the usage of this criterion may lead to different interpretation results. Having all these issues in mind, eliminating the lacuna in the ICC written law by the criteria enumerated in the Vienna Convention will not always lead to clear conclusions.

Focusing on the first layer of legal sources listed in article 21 paragraph 1a of the Statute, there are doubts with two issues: what is the relation between Rules of Procedure and Evidence or Elements of Crimes and the Statute, and more specifically, are Rules of Procedure and Evidence

${ }^{5}$ Vienna Convention on the law of treaties, concluded at Vienna on 23 May 1969, hereinafter referred to as "Vienna Convention" or "Convention".

${ }^{6}$ Prosecutor v. Thomas Lubanga Dyilo, Decision on the confirmation of charges, No.: ICC-01/04-01/06, 29 January 2007, para. 275-277. 
or Elements of Crimes the sources of lower category (lower importance) than the Statute? Furthermore, the question arises as to whether those sources are binding or whether they should be treated only as additional legal support for the ICC judges.

The hierarchy on the first level of legal sources does not result from article 21 of the Statute, and it can be deduced only from the particular provisions. By virtue of article 9 of the Statute, Elements of Crimes constitutes the legal assistance for the Court in interpreting and applying articles 6, 7 and 8 of the Statute, and furthermore, it should be consistent with the Statute. A similar provision can be found in the general introduction to Elements of Crimes, which provides that "Pursuant to article 9, the following Elements of Crimes will assist the Court in the interpretation and application of articles 6,7 and 8, consistent with the Statute" - and, what is even more important, that "The provisions of the Statute, including article 21 and the general principles set out in Part 3, are applicable to the Elements of Crimes". In the case of Rules of Procedure and Evidence, article 51 paragraph 4 of the Statute states, that RPE, amendments thereto, and provisional Rules cannot be inconsistent with the Statute. Furthermore paragraph 5 of the article commented on additionally provides, that in the case of inconsistency between the Statute and the Rules, the Statute will prevail. Thereby, the Statute has definitely obtained greater authority, since there cannot be any contradiction between RPE or EC and the Statute. The provisions of the Statute must be therefore treated as the standard of control.

As has already been pointed out above, in relation to article 9 of the Statute, some doubts have occurred as to whether Elements of Crimes is binding. Questions occur in relation to the expression that Elements of Crimes "will assist" the Court in interpretation of particular articles of the Statute. In this regard the Statute does not express precisely whether Elements of Crimes contains only guidelines for the ICC judges or if it has a binding nature. There is no such problem in the case of Rules of Procedure and Evidence, since none of the provisions of the Statute or RPE provides that Rules should be treated only as necessary assistance for the Court. Still, the ICC judicature clearly considers that EC (and also $\mathrm{RPE}$ ) are the sources of law that must be implemented in the application of the law, and any exceptions are acceptable only when the judges find a non-removable contradiction between the Statute and RPE or EC. 
Then, the Statute must take precedence ${ }^{7}$. One cannot disagree with this view, especially since article 21 of the Statute clearly specifies Rules of Procedure and Evidence and Elements of Crimes as two of the sources of law ${ }^{8}$. Also, the principle of nullum crimen sine lege, expressed in article 22 of the Statute, argues in favour of this statement, having in mind that Elements of Crimes contains provisions important to identify the crime.

Likewise, the status of other regulations remains unclear, for instance the Regulations of the Court ${ }^{9}$. These Regulations have been adopted by the ICC judges by an absolute majority, to the extent necessary for the functioning of the ICC. It is not clear as to what extent the Regulations are considered to be sources of law in the ICC's work, which can influence the rights and duties of parties, since they were not mentioned in article 21 of the Statute. This problem is of considerable significance, having in mind that Regulations establish many important matters, especially procedural time limits or other, technical issues, that parties have to comply with. The Regulations are not a treaty, nor an appendix to a treaty. Referring to article 31 paragraph 3 of the Vienna Convention, it is stated that the Regulations are a sort of subsequent agreement between parties, concerning the interpretation of the treaty and its provisions. In this way, the provisions of the Regulations must be taken into consideration not as the "context" of a treaty, but together with this context. Such a conclusion is allowed by the fact, that although the competence to adopt Regulations was conferred on the ICC judges, State Parties must have agreed to delegate their powers. Moreover, after adopting the Regulations, the State Parties have the right to submit their comments or objections, which will deprive the Regulations of legal power. Undoubtedly, even though it is not explicitly stated in the Statute, the Regulations affect the procedure before the ICC in such a way that we can consider the Regulations as the source of law.

7 Prosecutor v. Omar Hassan Ahmad Al. Bashir, Decision on the Prosecution's Application for a Warrant of Arrest against Omar Hassan Ahmad Al Bashir, No.: ICC-02/05-01/09, 4 March 2009, para. 128-131.

${ }^{8}$ More detailed considerations regarding this problem: G. Hochmayr, Applicable Law in Practice and Theory Interpreting Article 21 of the ICC Statute, "Journal of International Criminal Justice" 2014, vol. 12, pp. 657-659.

9 Hereinafter referred to as "the Regulations". 
The catalogue of legal sources was determined by number of general clauses, such as: "applicable treaties and the principles and rules of international law", "general principles of law derived by the Court from the national laws of the legal systems of the world", "internationally recognized norms and standards". This terminology always requires its own interpretation. The way legal sources are characterized proves that the ICC judges move in a much wider legal area than just the Statute and its accompanying regulations. Even at this point it must be stated, that the judges' role, in the case of a lack of applicable ICC regulations, is to interpret them from other sources of law, which have international character, and thereby, to shape already existing legal norms not taken into account by the Statute's creators.

According to art. 21 paragraph 2 of the Statute: "The Court may apply the principles and rules of law as interpreted in its previous decisions". During the negotiations of the treaties, this provision was a necessary compromise between States with civil law systems and States with common law traditions. Unfortunately, the Statute does not provide an answer to the question, to what point is the Court bound by its previous decisions? The logical consequence of placing the ICC's decisions in article 21 of the Statute, entitled "applicable law" is to treat them as one of the legal sources. But in this case, another problem occurs - the Statute's creators did not indicate the place of the judicature in the legal hierarchy. It also leaves unexplained to what extent the decision may be applied, especially, if the application of principles and rules resulting from the ICC's decisions is limited to ratio decidendi or if it also includes obiter dicta, which after all in common law systems do not create the law ${ }^{10}$. Referring to Anglo-Saxon tradition it can be stated that decisions should have, in general, persuasive and not binding power, since the Statute constitutes only the possibility of applying the ICC's decisions ${ }^{11}$. At this point it should be also mentioned, that the scope of article 21 paragraph 2 of the Statute does not include the decisions of ad hoc tribunals, although one can see in ICC case law a number of references to the existing case law of these tribunals.

${ }^{10} \mathrm{~S}$. Pomorski, American common law and the principle nullum crimen sine lege, Warszawa: PWN, 1975, p. 39-40.

11 Supra note 9 at p. 43. 
The difficulties in the interpretation process do not occur only from the legal sources perspective. The cause of problems in obtaining consistent results of interpretation is also the variety of legal cultures from which the ICC judges come. Article 36 paragraph 8 of the Statute provides that the election of judges should take into account the need to represent the world's principal legal systems. This entails weighty consequences on the interpretation perspective. The Statute includes the legal acquis of different legal systems, integrating civil law and continental law traditions. The legal backgrounds from which judges come unavoidably affect the way each legal institution is understood, and have an influence on the interpretation of provisions which constitute those institutions. The courts usually consist of more than one person (judge), so while investigating the case, many different views and opinions occur. Legal and cultural diversity is a significant factor affecting the process of legal interpretation.

The problems identified above are not the only difficulties in the process of interpretation. It has already been pointed out that owing to the multiplicity of views presented during the Statute's negotiations, a number of legal issues remain unresolved. This forces the ICC judges to supplement the statutory framework with their own solutions. A good example of this problem is that the Rome Statute does not contain provisions governing a "no case to answer" motion, which is typical for the common law tradition. This problem occurred, inter alia, in the case of the Prosecutor v. William Samoei Ruto and Joshua Arap Sang ${ }^{12}$ where the Trial Chamber considered such a motion as consistent with the Court's regulatory framework. The Chamber interpreted such a conclusion from the Rome Statute, having regard to the fact that such a motion "would be intended to be fulfilled in the distinctive institutional and legal context of the Court". This is only one of many examples of how the ICC copes with the lack of more specific regulations. Each time the Court needs to solve a dilemma, whether a particular institution is admissible in the light of the Statute, some additional interpretative activities are required.

12 Prosecutor v. William Samoeiruto and Joshua Arap Sang, Decision no. 5 on the conduct of trial proceedings (principles and procedure on 'no case to answer' motions), 3 June 2014, ICC-01/09-01/11-1334. 


\section{DIRECTIVES AND TYPES OF INTERPRETATION IN THE ICC'S WORK}

It has been stated above that the provisions of the Rome Statute require interpretation already at the stage of defining the catalogue of sources of law, and apparently also at other stages of proceedings. It is therefore necessary to consider what directives and types of interpretation are used by the ICC judges.

Interpretation directives provide the answer to the question of how should we interpret legal texts ${ }^{13}$. The Vienna Convention, which is applicable to the Rome Statute, indicates interpretational directives, which should be followed while interpreting a treaty ${ }^{14}$, i.e. grammatical interpretation, functional (teleological) interpretation, and systemic interpretation. In the light of this Convention grammatical interpretation should be understood as defining the meaning of a particular provision on the basis of the language used in the legal text, and more specifically "in accordance with the ordinary meaning" of the provision. Systemic interpretation amounts to the necessity of treaty interpretation in the light of its context, while functional interpretation requires also the consideration of the object and purpose of a treaty, in order to determine the meaning of an interpreted provision. These directives have, according to the Convention, equal weight in the process of interpretation ${ }^{15}$, although, pursuant to the objective approach, the final will of the parties to the treaty should emerge from the text of the provisions that manifest the

13 P. Wiatrowski, Dyrektywy wykładni prawa karnego materialnego w judykaturze Sadu Najwyższego [The directives of criminal law interpretation in Supreme Court's judicature], Warszawa: C.H. Beck, 2013, p. 1-33.

14 Art. 31 of Vienna Convention:,,A treaty shall be interpreted in good faith in accordance with the ordinary meaning to be given to the terms of the treaty in their context and in the light of its object and purpose".

${ }^{15}$ M. Kałduński, Kilka słów na temat interpretacji w prawie międzynarodowym. Uwagi na tle uchwaty Sądu Najwyższego z 19 lutego 2003 r., I KZP 47/02 (A few words on interpretation in international law. Remarks on the Supreme Court's resolution of 19 February 2003, I KZP 47/02), [in:] L. Morawski (ed) Wyktadnia prawa i inne problemy filozofii prawa [Law interpretation and other problems of legal philosophy], Torun: Wydawnictwo Uniwersytetu Mikołaja Kopernika, 2005, p. 69-71. 
parties' intentions ${ }^{16}$. Article 31 of the Convention shares this assumption, although it includes also the perspectives of teleological and subjectivist approaches ${ }^{17}$.

The difficulties mentioned above have a significant impact on the way in which interpretational directives are applied. The variety of legal cultures and axiological systems, the incompleteness of regulations, and the numerous legal clauses frequently prevent the determining the meaning of a provision using only grammatical interpretation, not to mention a situation when some issues are not reflected in written regulations at all. For these reasons, it is necessary to reach the directives of systemic and teleological interpretation.

The context in which a Statute's provisions are embedded, and by which we should understand mainly auxiliary regulations like Rules of Procedure and Evidence and Elements of Crimes, and along with the context of the Regulations, are the basis for using systemic interpretation. As has already been mentioned, Elements of Crimes develops the understanding of crimes depicted in article 5 of the Rome Statute, while Rules of Procedure and Evidence provides the Court with more detailed procedural rules, filling the procedural framework resulting from the Statute.

In the Court's work, the role of teleological interpretation also seems to be invaluable. Judges do not lose sight of the purpose of the ICC and the weight of cases recognized by the Court. Although procedural guarantees, especially the rights of the accused, require interpreting the Statute and other regulations in a way that as far as possible corresponds with the literal meaning of the provisions, other issues cannot be forgotten, for example issues related to procedural economy, the rights and safety of the victims and witnesses of crime ${ }^{18}$.

16 A. Szpak, O wykładni międzynarodowego prawa traktatowego i zwyczajowego ( $z$ uwzględnieniem międzynarodowego prawa humanitarnego) [About interpretation of international law of treaties and customary law (including international humanitarian law)], "Ruch Prawniczy, Ekonomiczny i Socjologiczny" 2008, Year LXX, issue 1, p. 75.

17 M. Frankowska, Prawo Traktatów [The law of treaties], Warszawa: Szkoła Główna i Handlowa w Warszawie - Oficyna Wydawnicza, 2007, p. 122-123.

18 Prosecutor $v$. Thomas Lubanga Dyilo, Decision on the confirmation of charges, No.: ICC-01/04-01/06, 29 January 2007, para. 37-39. 
The Vienna Convention remains silent on historical interpretation, which can be understood as the process of defining the meaning of a particular provision in the light of the evolution of this provision or on the basis of other, similar provisions ${ }^{19}$. However, the ICC judges often refer to the historical context, even using the ad hoc tribunals' case law and comparative analysis of those tribunals' statutes ${ }^{20}$. Regular elements of ICC decisions are thus elements of comparative interpretation. Moreover, the ICC judges have recourse to the documentation of the negotiations leading to the Statute (travaux préparatoires), in order to determine the reasons which the State Parties had in mind in accepting the Statute ${ }^{21}$. In that regard the interpretation leads to the reconstruction of the will of the parties to the Rome Statute, which is characteristic for the subjectivist concept of treaty interpretation.

While defining the interpretation carried out by the Court, it is necessary to refer to the types of interpretation distinguished in jurisprudence. According to a widely recognized concept, with regard to the person of the interpreter, we can distinguish, inter alia, authentic interpretation (conducted by a person who creates the law), operative interpretation (carried out by a person who applies the law) or doctrinal interpretation (carried out by representatives of jurisprudence sciences) ${ }^{22}$. The interpretation made by the ICC judges has, without a doubt, the character of operative interpretation, conducted for the purposes of a specific case by an international body responsible for applying the law. Of course, we must have in mind the question of whether ICC decisions (for example decisions of the Appeal Chamber) are also binding in other cases. Additionally, each legal regulation can be adopted by the judges

19 P. Wiatrowski, Dyrektywy wykładni prawa karnego materialnego w judykaturze Sadu Najwyższego [The directives of criminal law interpretation in Supreme Court's judicature], Warszawa: C.H. Beck, 2013, p. 33-34.

${ }_{20}$ Prosecutorv. Germain Katanga and Mathieu Ngudjolo Chui, Decision on the confirmation of charges, No.: ICC-01/04-01/07, 30 Septemberr 2008, para. 395, 401.

${ }^{21}$ Prosecutor v. Mathieu Ngudjolo Chui, Judgment pursuant to article 74 of the Statute, Concurring opinion of Judge Christine Van den Wyngaert,No.: ICC-01/04-02/12, 18 December 2012, para. 13, 23, 31.

${ }_{22}$ M. Zieliński, Wyktadnia prawa. Zasady. Reguty. Wskazówki [The interpretation of law. Principles. Rules. Guidelines], Warszawa: Wydawnictwo Prawnicze LexisNexis, 2002, p. 59-61. 
themselves (for example the Regulations). This way the ICC is not only the authority applying the law, but also the authority creating the law, which is characteristic of authentic interpretation. Doctrinal interpretation may by contrast be an invaluable source of knowledge and interpretational ideas for judges ${ }^{23}$.

The results of interpretation vary depending on the character (material or procedural) of interpreted provisions. Most of the time, the Court makes a literal interpretation, which is consistent with the nullum crimen sine lege principle and with the guarantees of criminal law However, in many cases, as a result of applying directives of systemic and teleological or even historical interpretation, the effects of extensive interpretation can be seen ${ }^{24}$. At the same time, the Court looks with caution upon restrictive interpretation, which can narrow the meaning of particular provisions in comparison with the results of literal interpretation. Especially the Court does not allow restriction of the scope of the Rome Statute owing to Rules of Procedure and Evidence interpretation ${ }^{25}$.

\section{THE CREATIVE CHARACTER OF INTERPRETATION IN THE ICC'S WORK}

As a result of the difficulties in the process of interpretation of statutes and the necessity of interpreting legal norms from other legal sources, the interpretation performed by the ICC has a specific character. In situations which require special interpretative measures, judges evaluate and give concrete expression to legal norms, rules, and principles, already existing in international or national laws, constituting norms for the purpose of a specific case. It must be pointed out once again, that article 21 of the Rome Statute clearly authorizes the ICC judges to look for inspiration and deal with legal questions referring to applicable treaties, principles,

${ }^{23}$ About authentic, operative, and doctrinal interpretation see: L. Morawski, Wstęp do prawoznawstwa [Introduction to jurisprudence], Torun: Wydawnictwo Dom Organizatora, 2006, p. 163-166.

${ }^{24}$ Prosecutor v. Thomas Lubanga Dyilo, Judgment on the appeal of Mr Thomas Lubanga Dyilo against his conviction, No. ICC-01/04-01/06 A 5, 1 December 2014, para. 53-64.

${ }^{25}$ Situation in the Democratic Republic of Congo, Decision on applications for participation in the proceedings, No. ICC-01/04, 17 January 2006, para. 47. 
and rules of international law or general principles of law derived from national laws of the legal systems of the world. Although the sources are more or less specified, legal standards resulting from these sources need an instance and must be shaped according to specific requirements of proceedings before the ICC.

This process of interpretation should be assessed on two levels. On the Statute, Rules of Procedure and Evidence and Elements of Crimes level, when judges render decisions based on legal norms which are not reflected in above mentioned regulations, those judges basically create legal norms themselves, not only for a single case, but also for future purposes. It should be remembered that judicial decisions, according to article 21 of the Statute, may become the basis of subsequent decisions. Any decision that contains a solution to some legal problem is a potential source of legal norms, which can affect future proceedings. ICC case law provides indications not only for the judges, who investigate similar matters, but also for the parties (prosecution, defendant) and legal representatives of the parties, who commonly refer to previous legal concepts.

Looking from another perspective - the perspective of national laws and international law, judges in fact give specific, concrete expression to already existing legal norms, for the purpose of the factual background of the case. These norms cannot be applied directly, but mutatis mutandis, subject to the special purpose and role of the ICC.

In situations where judges perceive a lacuna in "written law", the interpretation of the Statute's provisions and other accompanying regulations includes the norms interpreted from external legal orders. It must be noted that, even if some statutory regulations raise only insignificant doubts, the solution adopted for the purpose of a specific case, inspired by rules and principles taken from other legal orders, introduces new standards or strengthens already existing views for future legal proceedings.

Interpretation, such as that mentioned above, may be called creative interpretation, because of its creative character. In other words, creative interpretation conducted by the ICC is the interpretation of the Statute and the provisions of the accompanying regulation, made with regard to the objectives and functions of the ICC, rooted in rules and principles already existing in the area of international and national laws, by which a new statutory norm occurs. 
It should be noted, however, that the ICC judges do not have full discretion in shaping legal norms. The content of the Statute, as a manifestation of the will of the State Parties, limits the results of creative interpretation. This is reflected inter alia in provisions that provide consistency between the Statute and other legal sources which might be applied by the ICC judges. Each time the Court needs to consider the admissibility of a particular legal institution, the first and most important question is whether it is consistent with the ICC regulatory framework, in particular with the Statute. The Statute has, for this reason, a limiting function.

Furthermore, the condition for the admissibility of such creative interpretation is its compliance with internationally recognized human rights ${ }^{26}$. This condition clearly results from article 21 paragraph 3 of the Statute, and finds additional confirmation in article 69 paragraph 7 of the Statute, on the ground of admissibility of evidence.

The results of interpretation must be confronted with the rights of defendants, victims and witnesses, and with pragmatic or economic considerations. Interpretative discretion and eliminating legal loopholes must not stand in contradiction to the principles and functions of the criminal law and procedure, first and foremost, with regard to to the nullum crimen sine lege principle. This view finds confirmation in a recent judgment, according to which the methods of interpretation stated in the Vienna Convention "need to be applied taking into account the nature of the Statute, in particular, with respect to its incriminating provisions. Its interpretation must be guided by the principle of legality. Notably, any interpretation of such provisions must comply with the principle of strict construction under article 22 (2) of the Statute ${ }^{27}$.

Having regard to all the forgoing, the ICC judges, despite all the limitations mentioned above, create norms applicable by the Court, thereby giving new life to particular legal institutions and legal concepts.

${ }^{26}$ Prosecutorv. Germain Katanga and Mathieu Ngudjolo Chui, Decision on the confirmation of charges, No.: ICC-01/04-01/07, 30 September 2008 r., para. 93-99.

27 Prosecutor v. Jean-Pierre Bemba Gombo, Aimé Kilolo Musamba, Jean-Jacques Mangenda Kabongo, Fidèle Babala Wandu and Narcisse Arido, Judgment on the appeals of Mr Jean-Pierre Bemba Gombo, Mr Aimé Kilolo Musamba, Mr Jean-Jacques Mangenda Kabongo, Mr Fidèle Babala Wandu and Mr Narcisse Arido against the decision of Trial Chamber VII entitled "Judgment pursuant to Article 74 of the Statute", No. ICC-01/05-01/13, 8 March 2018, para. 11. 


\section{CONCLUSIONS}

Establishing the International Criminal Court during the Rome Conference was an unquestionable success in international criminal policy. However, combining different viewpoints and different legal traditions has led to the introduction of a regulation that is indeed imperfect, incomplete, and leaves considerable latitude for its interpreters.

In the light of the above considerations, applying the Statute requires interpretational activity and engagement. The way in which the Statute is worded, especially in how the legal sources are determined, causes the process of interpretation to begin with the stage of assessing what is the law, and how it should be interpreted. Nevertheless, including article 21 in the Statute was necessary so as to provide judges with the ability to search for legal inspiration from other legal systems, and in this way, to supplement the legal area in which the Court exists. It should not be considered an exaggeration to say that for over a decade the ICC judges have been shaping the legal framework of the International Criminal Court. Some legal problems have already been resolved, while other issues are still waiting for their turn.

Undoubtedly also the multiplicity of views within particular divisions of the Court may be considered as a big challenge in the process of interpretation. However, having in mind that according to the Statute, in the selection of judges, states must take into account, among other things, the need for the representation of the principal legal systems of the world, the plurality of views is inherent in proceedings before the Court, and therefore should be treated as a guarantee of the comprehensive examination of any legal problem.

Although in national legal orders, it is assumed that creative interpretation should be applied only in certain cases, since judicial power is not allowed to encroach on the competence of legislative bodies, it seems that the ICC framework does not allow for such conjecture. Judicial initiative and the power of Court's decisions are the necessary tools allowing the Court to function and to exercise its jurisdiction, despite of interpretative problems. 
